\title{
Susan Lewis
}

Music in the Baroque World: History, Culture and, Performance. New York: Routledge, 2016. Pp. 376. Hb, \$16o.

In its Preface, this book claims to offer "an interdisciplinary approach" balancing "detailed analysis of specific pieces of music and broader historical overview and relevance," as well as a companion website connecting "all music analyzed in the textbooks with recordings and scores," including "links to fiftythree tracks from Spotify and iTunes" (xviii). Attempting to set a wider historiographical and cultural context for important baroque musical works studied by music undergraduates, the intentions are laudable. The inclusion of select historical documents (and a chronological ordering of material) also supports the author's desire to "bring the world of Baroque music-making a bit closer to college and university students" (xvii). Unfortunately, militating against these aims are enough errors in the narrative to suggest that the book was not proofread to a sufficient academic standard.

Dealing firstly with positive attributes, the chapter on the Americas (claiming to illustrate an innovative "global perspective"), with its broad discussion of colonial music in the Spanish Americas, New France and New England, is useful. The material on the latter two territories may well be a first, but chapters on baroque music in the Spanish Americas have appeared in earlier texts designed for undergraduates. Gerard Behague's Music in Latin America: An Introduction (New Jersey: Prentice-Hall History of Music Series, 1979), is a comprehensive volume which not only mentions Manuel de Zumaya (c.1678-1755) (who receives some attention in Lewis's text), but also many other important musicians, such as Juan de Araujo (1646-1712), Domenico Zipoli (1688-1726), and Antonio Sepp (1655-1733), the latter two having been Jesuits working in Paraguay, whose music has recently received scholarly attention. I was therefore surprised to see Zipoli omitted when, albeit briefly, Jesuit activity in Canada was included. The Jesuits were at the epicenter of Counter-Reformation music throughout world for two centuries, yet the index contains just one reference, in regard to the Relations (344). However, the Jesuits feature on pages 52, 59, 139 and 343 , but are not indexed.

I was not overly bothered by the misspelling, on the first page, of Giovanni Gabrieli's (c.1557-1612) surname as Gabrielli in the "Timeline of Important Works, Composers and World Events," but what initially appeared as an unfortunate typographical slip was a sign of things to come. The timeline could have been helpful, but without its many misspellings, factual errors, and unclear expression. Why does the Thirty Years' War appear in italics, when it is produced in standard text elsewhere? Why is Heinrich Schütz's Daphne (1627) described as the "first Germany opera" when Germany, in a national sense, did not exist at 
that time? Next to 1660 is written "Restoration of the Monarchy and Charles II in England (until 1685)," so students unfamiliar with Stuart history might assume that the Restoration period ended in 1685 , when of course the generally accepted date is 1714. For 1687 the statement "Henry Purcell's Dido \& Aeneas performed at court of James II" is made without any apparent knowledge of the latest research in regard to the work's contentious chronology. The date 1695 includes Georg Muffat's Florilegium, without indicating that this was the Primum, the Secundum having followed in 1698 . The date 1717 has "Lady Mary Wortly" introducing inoculation against smallpox, but her correct full name is Lady Mary Wortley Montagu. For 1725 the compiler states "Catherine the Great assumes power in Russia," yet the empress was actually born in 1729. Alarmingly, Catherine II ("the Great") has been confused with the insignificant Catherine I, who did assume power in 1725, as the widow of Peter I, but who reigned for just two years.

Errors are not confined to the timeline. In Chapter 1, page 6, the author refers to the Dresden chapel master's post having gone, in 1655, to "the Italian singer Paranda." Presumably she meant Marco Giuseppe Peranda (1625-75) who sometimes appears in contemporary documents as "Perande" or "Perandi," but never "Paranda," a spelling also used in the index. On page 7 discussion refers to the singer Carlo Broschi (known by his stage name Farinelli), but the caption to his portrait on page 8 has "Brioschi." In Chapter 4, concerning music and religion, the term a capella is used when spelling cappella with two p's is preferable. Proofreading failures continue with Chapter 7 , where, immediately under a sub-heading "Louis xIV: The Boy King" (138), the text begins with "Louis IV's birth in 1638 ." On page 141 of the same chapter a paragraph begins "In 1672 Louis XIV charged Jean-Baptiste Lully (1599-1667) with establishing a Royal Academy of Music, when Lully's correct dates are 1632-87. We then read that Lully was "born in Florence in 1632." The author also translates the opening text of Domine salvum fac Regem as "Grand Victory to the King, O Lord" when "Lord, save [our] King" is correct.

Chapter 8 deals with Restoration England. Since Charles II died in February 1685 he cannot have ruled, as the text states, from "166o-86." The assertion on page 183 that James II's "open support of Catholicism was expressed in his preference for ritual and Italian music" would have been more accurately reinforced, at that point, by acknowledging that James was a Roman Catholic, who built a grand, expensive Royal Catholic Chapel at Whitehall in 1686. Claims that Pepys "chronicled the Catholicization of London in his diary" and that he objected to "ritual and Italianate music" are exaggerated and unfair. John Evelyn was more outspoken on the former, and for the latter, Pepys's references to the Italian music of the Catholic chapel of Catherine of Braganza in his first diary (1660-69) were not always negative, and he was enthusiastic for Carissimi's music. Pepys even used his influence to help his Italian guitar teacher, 
Cesare Morelli, seek employment under James II. The author states (192) that the tune "Greensleaves" "appears in all ten editions of (John Playford's) The Dancing Master' published before 1700." The first edition of the work appeared in 1651 , and there were ten editions before 1700, but the tune "Green Sleeves and Pudding Pies" (as it appears in seventeenth-century English sources) did not appear until the seventh edition (1686) and only four pre-170o editions included it. Whilst the tune was arguably the "verifiable hit of the late seventeenth century" which the author claims, her argument would have been strengthened by mentioning its appearance as a Ground with divisions in Playford's New Lessons for the Citharen (London, 1652) and in Playford's The Division Violin (London, 1684 and subsequent issues). Later, having referred to Henry Purcell's Sonnata's of III Parts, they are misspelled as "Sonnadas" in the conclusion. In the section on dramatic music, why, when discussing Psyche (1675) were both the composer and librettist (Matthew Locke and Thomas Shadwell) mentioned, when, in the next paragraph on Albion and Albanius (1685), there is no reference to its composer Louis Grabu, especially when the Locke entry in the index (which omits Shadwell) refers to Psyche? The view that Albion and Albanius was "an experiment," which "did not provide a new and workable model for uniting music and poetry in the service of a narrative" is severely at odds with the view of Grabu authority Bryan White, who believed its importance "as a work combining music, poetry, drama, scenic display and dance cannot be overemphasized," and that with it "these arts are thoroughly integrated and interdependent" (Purcell Society Edition, 1:xix).

In Chapter 9 on music for the stage in Europe's big cities, the castrato Senesino is described as "Francesco Bernardi Senesino" when his real name was Bernardi, and Senesino (like Farinelli), was his stage name. Quite a lot of discussion is devoted to Telemann's intermezzo Pimpinone (1725), except that it is repeatedly referred to as "Pimpinione" on page 231. Chapter 10 deals with the solo concerto, but refers to the (unindexed) San Petronio master Maurizio Cazzati as "Cazzata." Some may consider the errors I have mentioned to be minor, but if we are to reinforce amongst undergraduates the importance of accuracy and clear expression, then surely the correct spellings of important names and work titles is a basic requirement. It is disappointing that a book which contains, overall, useful analytical commentaries and historical and cultural cross-references, has been marred by so many distracting and unhelpful faults.

\footnotetext{
Peter Leech

Cardiff University leechp@cardiff.ac.uk

DOI 10.1163/22141332-00401005-11
} 